\title{
An Analysis of Acceleration and Speed Performances Through the Positions in Handball
}

\author{
Cengiz Taşkın (Corresponding author)
}

Department of Physical Education and Sport, School of Physical Education and Sport

Kilis 7 Aralık University, Mehmet Sanlı Mah. Doğan Güreş Paşa Bul. No:134 Kilis, Turkey

Tel: 90-348-814-2666_E-mail: taskin.c@hotmail.com

\begin{abstract}
Ali Kemal Taşkın
Department of Physical Education and Sport, School of Physical Education and Sport

Kilis 7 Aralık University, Mehmet Sanlı Mah. Doğan Güreş Paşa Bul. No:134 Kilis, Turkey

Tel: 90-348-814-2666Ｅ-mail: kemaltaskin@kilis.edu.tr
\end{abstract}

Received: September 15, 2021

Accepted: October 27, 2021

Published: November 11, 2021

doi:10.5296/jei.v7i2.19010

URL: https://doi.org/10.5296/jei.v7i2.19010

\begin{abstract}
This research was conducted in order to compare the acceleration and speed performances of handball players according to their positions. A total of 60 male handball players that includes 5 goalkeepers, 15 middle playmakers, 7 right playmakers, 8 left playmakers, 7 right wingers, 8 left wingers and 10 pivots who actively play handball in the 2nd league of the Turkish handball federation has participated in the study voluntarily. Average age of the subjects participating in the study is determined as $19.5 \pm 1.43$ for the goalkeepers, $19.3 \pm 1.35$ for the right-left playmakers, $18.7 \pm 1.29$ for the right-left wingers, $19.1 \pm 1.89$ for the pivot players. Acceleration and speed performances of the subjects were measured in accordance with the measurement technique and all the data obtained were analyzed in the SPSS 20.0 software package program. Results that is obtained is examined, it is seen that the best values in terms of acceleration and speed performance were the performance values of right-left playmakers and right-left wing players, while the worst performance values belonged to pivot players. As a result of our study, it was observed that athletes have different physical performances in handball according to their playing positions.
\end{abstract}

Keywords: Handball, Acceleration, Speed, Positions 


\section{Introduction}

Handball is a team sport that is played around the world. It is a combined activity, in which various movements are performed together with the aim of playing a good game and establishing superiority against the opponent together with their teammates by showing high performance just like as the most sports (Bağırgan, 1990).

On the other hand, modern handball has turned into a fast game that demands superior sports performance from the athletes with the changing rules. It is a fast and dynamic sport that requires physical strength. When it is looked at the physical characteristics of handball players, it is seen that they are tall, have long arms and legs and they can use their body weight relative strength at an optimal level. It is seen that handball players have a body weight above the average, but their body fat percentage is below the average too (Y1ldirım, 1997).

Although techniques and tactics have an important place in handball, the advantages of the physical characteristics of handball players are more essential. A great start and sprinting ability is essential for fast rushes that are common during gameplay. As it mentioned here, although many features have an important place in handball sport, acceleration and speed can be shown among these features (Brown, 2009). Travis defined the concept of speed as the product of stride length and stride frequency (Brown, 2009). Although running on a straight axis is a key athletic factor, it has been emphasized that high speed performance and acceleration constitute the majority in response to a stimulus in many different branches, especially team sports (Bradshaw, Young, Russell, \& Burge, 2011; Mann et al., 2016).

In handball competitions, shooting force and physical properties are extremely important in jumping, falling, twisting, and body deception (Taşucu, 2002). In addition to all these, athletes must have different physical and motor characteristics according to the positions they play. For example, the expectations of the coach from a winger and a middle quarterback can be very different.

In the field of sports sciences, although there are many studies on physical and motoric properties in handball as in many branches, there are not many studies examining the physical and motoric characteristics of the players in handball according to the positions they play. In this study that we did, we tried to examine the speed and acceleration performances of handball players according to the positions they play.

\section{Method}

\subsection{Participants}

A total of 60 male handball players that includes 5 goalkeepers, 15 middle playmakers, 7 right playmakers, 8 left playmakers, 7 right wingers, 8 left wingers and 10 pivots who actively play handball in the 2 nd league of the Turkish handball federation has participated in the study voluntarily. Before the study, the athletes were informed about the measurements and about their nutrition and rest for 24 hours before each measurement. Measurements were made in Kilis 7 Aralık University School of Physical Education and Sports Gym. 
Height: The height of the athletes was measured without their shoes on, holding their breath and standing firmly with both toes and heels together, in accordance with the measuring technique with a stadiometer (SECA, Germany) with a sensitivity of $0.01 \mathrm{~m}$.

Body Weight: Body weight measurements of the athletes were measured without shoes and sportswear (shorts and t-shirts) with an electronic scale (SECA, Germany) with a precision of $0.1 \mathrm{~kg}$.

Body Mass Index Calculation (BMI): The body mass index of the subjects was calculated by dividing the body weight in kilograms by the square of the height in meters with the formula accepted by the World Health Organization:

Body Mass Index $(\mathrm{BMI})=$ Body Weight $(\mathrm{kg}) /$ Square of height $\left(\mathrm{m}^{2}\right)$.

Acceleration Test: The track was continued in the same direction with a length of 15 meters. It was divided into three sections which were 5, 10 and 15 meters. Two slalom and one photocell were installed for each five meters. It was consisting of 6 slalom and three photocells in total. The person who will enter the track has been brought to the starting point by calling their name, and it was ensured that he took the running position with one of his feet bent at the knee and the other one straight at the back. He was not allowed to take a step back. After waiting in that position for a maximum of 3 seconds, he had started running at maximum speed with the ready and exit commands. Measurement results were written in seconds and each athlete was given 3 attempts. All subjects were not allowed to proceed to the second attempt until the first attempt was over. The best graded trials of the athletes who completed all three trials at 5,10 and 15 meters have been recorded.

30 M Speed Run: Measurements were made on a standard $45 \mathrm{~m}$ indoor running track. Its length and ground characteristics were the same for all subjects. The start and finish lines are set in a ground with a straight line. At the starting and $30 \mathrm{~m}$. ending line, photocell is placed. In addition, the starting and ending points are determined with signs (funnel, etc.). The subjects were given three trials and a five -minute rest between each trial and the best time of the three trials was evaluated.

\subsection{Statistical Analysis}

All data obtained in the study were analyzed in the SPSS 20.0 software package program. Whether the data has showed normal distribution or not was determined by using the Kolmogorov-Smirnov test. Since it showed normal distribution, one-way analysis of variance, One-Way Anova test, was used to determine whether the acceleration and speed values of the handball players differ according to their positions. As a result of the comparisons, Tukey HSD method which is one of the Post Hoc multiple comparison tests was used to determine between in which groups the difference has occurred. In this study, the significance level was taken as 0.05 . 


\section{Results}

Table 1. Descriptive statistical values for the subjects' number of playing positions

\begin{tabular}{|l|l|l|}
\hline Variables & N & Percentage (\%) \\
\hline Goalkeeper & 5 & 8.33 \\
\hline Middle Playmaker & 15 & 25.00 \\
\hline Left-Right Playmaker & 15 & 25.00 \\
\hline Left-Right Winger & 15 & 25.00 \\
\hline Pivot Player & 10 & 16.67 \\
\hline Total & $\mathbf{6 0}$ & $\mathbf{1 0 0 . 0 0}$ \\
\hline
\end{tabular}

When Table 1 is examined, it is observed that the number and percentage values of the group that participated in the research are discussed.

Table 2. Descriptive statistical values for the subjects that participated in the study

\begin{tabular}{|c|c|c|c|c|c|}
\hline \multirow[t]{2}{*}{ Variables } & Goalkeeper & $\begin{array}{l}\text { Middle } \\
\text { Playmaker }\end{array}$ & $\begin{array}{l}\text { Left-Right } \\
\text { Playmaker }\end{array}$ & $\begin{array}{l}\text { Left-Right } \\
\text { Winger }\end{array}$ & Pivot Player \\
\hline & \multicolumn{5}{|c|}{ - } \\
\hline Age (year) & $19.5 \pm 1.43$ & $19.3 \pm 1.35$ & $18.7 \pm 1.29$ & $19.1 \pm 1.89$ & $19.8 \pm 1.54$ \\
\hline Height (cm) & $180.6 \pm 2.12$ & $177.2 \pm 2.82$ & $178.4 \pm 2.83$ & $176.6 \pm 3.18$ & $183.8 \pm 3.25$ \\
\hline Weight (kg) & $78.45 \pm 3.23$ & $75.47 \pm 2.72$ & $75.81 \pm 2.98$ & $74.93 \pm 3.01$ & $84.78 \pm 3.37$ \\
\hline BMI $\left(\mathrm{kg} / \mathrm{m}^{2}\right)$ & $24.05 \pm 1.12$ & $24.03 \pm 0.97$ & $23.82 \pm 0.82$ & $23.99 \pm 0.79$ & $25.09 \pm 1.04$ \\
\hline
\end{tabular}

When Table 2 is examined, the statistical data of the age, height, weight and body mass index average values of the subjects were given according to their playing positions. 


\section{Macrothink}

Table 3. Comparison of the physical parameters of the subjects according to their playing positions

\begin{tabular}{|c|c|c|c|c|c|c|}
\hline Variables & Positions & Average & Standard Deviation & $\mathbf{F}$ & $\mathbf{P}$ & Gap \\
\hline \multirow{5}{*}{ Age (year) } & Goalkeeper & 19.5 & 1.43 & 0.857 & 0.473 & \\
\hline & Middle Playmaker & 19.3 & 1.35 & & & \\
\hline & Left-Right Playmaker & 18.7 & 1.29 & & & \\
\hline & Left-Right Winger & 19.1 & 1.89 & & & \\
\hline & Pivot Player & 19.8 & 1.54 & & & \\
\hline \multirow{5}{*}{ Height (cm) } & Goalkeeper & 180.6 & 2.12 & 8.748 & $0.000^{*}$ & $1-4$ \\
\hline & Middle Playmaker & 177.2 & 2.81 & & & $2-5$ \\
\hline & Left-Right Playmaker & 178.4 & 2.83 & & & $3-5$ \\
\hline & Left-Right Winger & 176.6 & 3.18 & & & $4-5$ \\
\hline & Pivot Player & 183.8 & 3.25 & & & \\
\hline \multirow{5}{*}{ Weight $(\mathrm{kg})$} & Goalkeeper & 78.45 & 3.23 & 7.417 & $0.000^{*}$ & $1-5$ \\
\hline & Middle Playmaker & 75.47 & 2.72 & & & $2-5$ \\
\hline & Left-Right Playmaker & 75.81 & 2.98 & & & $3-5$ \\
\hline & Left-Right Winger & 74.93 & 3.01 & & & $4-5$ \\
\hline & Pivot Player & 84.78 & 3.37 & & & \\
\hline \multirow{5}{*}{ BMI $\left(\mathrm{kg} / \mathrm{m}^{2}\right)$} & Goalkeeper & 24.05 & 1.12 & 1.918 & $0.047^{*}$ & \\
\hline & Middle Playmaker & 24.03 & 0.97 & & & $3-5$ \\
\hline & Left-Right Playmaker & 23.82 & 0.82 & & & $4-5$ \\
\hline & Left-Right Winger & 23.99 & 0.79 & & & \\
\hline & Pivot Player & 25.09 & 1.04 & & & \\
\hline
\end{tabular}

Note. 1: Goalkeeper; 2: Middle Playmaker; 3: Left-Right Playmaker; 4: Left-Right Winger; 5:Pivot Player; *: Significance at $\mathrm{p}<0.05$ level.

When Table 3 is examined, it was determined that the players playing in the goalkeeper and pivot zone were taller than the players in other zones in the height variable while comparing the physical parameters of the handball players according to their game positions $(p<0.05)$. When the weight variable according to the positions of the athletes is compared, it was found that the players playing in the pivot area were overweight than the other players $(p<0.05)$. When the BMI values were compared, it was determined that the athletes playing in the pivot 
area had higher body mass index than the right and left playmakers and right and left wing players $(p<0.05)$. All of these datas were statistically significant.

Table 4. Comparison of the acceleration and speed values of the subjects according to their positions

\begin{tabular}{|c|c|c|c|c|c|c|}
\hline Variables & Positions & Average & Standard Deviation & $\mathbf{F}$ & $\mathbf{P}$ & Gap \\
\hline \multirow{5}{*}{5 Meters (sn) } & Goalkeeper & 1.04 & 0.06 & 2.319 & $0.031^{*}$ & \\
\hline & Middle Playmaker & 1.03 & 0.05 & & & $3-5$ \\
\hline & Left-Right Playmaker & 1.01 & 0.08 & & & $4-5$ \\
\hline & Left-Right Winger & 0.99 & 0.04 & & & \\
\hline & Pivot Player & 1.09 & 0.10 & & & \\
\hline \multirow{5}{*}{10 Meters (sn) } & Goalkeeper & 1.75 & 0.12 & 4.298 & $0.001^{*}$ & \\
\hline & Middle Playmaker & 1.73 & 0.10 & & & \\
\hline & Left-Right Playmaker & 1.71 & 0.11 & & & $3-5$ \\
\hline & Left-Right Winger & 1.69 & 0.08 & & & $4-5$ \\
\hline & Pivot Player & 1.80 & 0.15 & & & \\
\hline \multirow{5}{*}{15 Meters (sn) } & Goalkeeper & 2.35 & 0.13 & 2.601 & $0.023^{*}$ & \\
\hline & Middle Playmaker & 2.33 & 0.09 & & & $3-5$ \\
\hline & Left-Right Playmaker & 2.28 & 0.11 & & & $4-5$ \\
\hline & Left-Right Winger & 2.29 & 0.12 & & & \\
\hline & Pivot Player & 2.40 & 0.13 & & & \\
\hline \multirow{5}{*}{30 Meters Speed (sn) } & Goalkeeper & 4.60 & 0.13 & 3.159 & $0.008^{*}$ & $1-5$ \\
\hline & Middle Playmaker & 4.59 & 0.11 & & & $2-5$ \\
\hline & Left-Right Playmaker & 4.57 & 0.12 & & & $3-5$ \\
\hline & Left-Right Winger & 4.54 & 0.18 & & & $4-5$ \\
\hline & Pivot Player & 4.71 & 0.15 & & & \\
\hline
\end{tabular}

Note. 1: Goalkeeper; 2: Middle Playmaker; 3: Left-Right Playmaker; 4: Left-Right Winger; 5: Pivot Player; *: Significance at $\mathrm{p}<0.05$ level.

When Table 4 is examined, the 5-10-15 meters acceleration distance scores of the right and left playmaker and the right and left wing players are statistically better than the 5-10 and 15 
meters acceleration distances of the pivot players in termns of comparing the 5-10 and 15 meters acceleration degrees of the handball players according to their playing positions. When the 30-meter speed performance levels of the athletes participating in the study are compared, it was determined that the 30-meter speed degrees of the goalkeeper, middle quarterback, right and left point guard and the athletes playing in the right and left wing regions were statistically better than the 30 -meter speed degrees of the athletes playing in the pivot area $(\mathrm{p}<0.05)$.

\section{Discussion}

Handball sport is a complex sport that requires high performance in which aerobic and anaerobic systems are used together. However, factors such as speed, strength, flexibility, agility and balance have a great effect on the performance. In the study that it is examined that the acceleration and speed performances according to the positions of players in handball, the average height of the athletes was found to be $179.4 \pm 2.52$, the average weight to be $77.89 \pm 3.14$, and their body mass index to be $24.39 \pm 0.93$. While comparing the physical characteristics of the players in terms of positions, it was determined that goalkeepers and pivot players had the highest height, maximum weight and highest body mass index values. In a study conducted with elite handball players, the average height values of the athletes were found to be $184.8 \mathrm{~cm}$ (Tillaar, 2004). It is thought that the small difference between the two studies, which is observed to be close to each other, is due to the levels of the leagues that the players play in it. In a study conducted on female handball players, it was observed that the tallest players were goalkeepers and the shortest players were the players who played as a winger in the evaluation of the average height according to the positions played by the athletes (Ateşoğlu \& Tamer, 1999).

When body mass index of elite handball players is examined according to their positions in another study, it was found that wingers has the lowest body mass index values, while pivot players has the highest (Şentürk, 2016). We can say that the values in the results of the study and the values in our study overlap with each other.

When the 5-10 and 15-meter acceleration degrees were compared in another body mass study of elite handball players, it was found that wingers had the best values and pivot players had the worst ratings. Furthermore, when the 30 -meter speed performance grades of the athletes that participated in the study were compared, it was observed that wingers had the best grades, while pivot players had the worst grades.

When we examine the studies in the literature; it can be found that sprint performances of elite handball players in 10 meters, 20 meters and 30 meters. In all of these sprint performances, it has been determined that the wing and playmakers have the best grades, and the worst grades belong to the athletes playing in the pivot and goalkeeping positions (Şentürk, 2016). In Chaouachi et al. (2009) study on elite handball players, 10 and 30 meter sprint performances were measured and it was observed that the best scores were measured by the wingers and playmakers and the worst scores had by pivot players and goalkeepers. In two studies that is conducted on female and male handball players in 2014 and 2015, it was found that the average speed reached by athletes during the match was higher in men than 
women, while athletes who are wingers in both genders reached higher values than pivots and playmakers (Michalsik et al., 2015; Póvoas et al., 2014). When we examine the results of the study in the literature and the results of our study, it can be said that the results of the study are in parallel with each other. In modern handball, wingers are believed to be faster than other players in terms of speed performance. Wingers must be the first to take the fast break during the competition and have to enter the assault position after high positive acceleration in order not to touch the opponent when they pass the wing position, and the players playing in this position must be fast.

In the literature, when we examine the studies in different branches and parameters according to the game positions, the reaction time of the players was compared according to their positions in a study on football players and it was observed that goalkeepers had the best time in reaction times (Taşkın et al., 2016). In addition, average and peak anaerobic power values were examined according to positions in another study by Taskin et al. (2020) on handball players and it was observed that right and left wing players had the best values while pivot players had the worst values. As a result of examining the firing rate values according to the positions in handball, it was reported that goalkeepers have a higher rate of fire than left-right playmakers, mid-playmakers and right-left wing players, and that athletes playing in the pivot position have a higher firing rate than goalkeepers (Shalfawi et al., 2014). As it can be understood from the studies, we can say that the athletes have different characteristics according to their positions regardless of the branch.

As a result of our study, it was observed that athletes have different physical performances in handball according to their positions. We think that taking into account the physical and biomotor skills of the athletes and assigning them to the appropriate position during the competition will increase the success.

\section{References}

Ateşoğlu, U., \& Tamer, K. (1999). Türkiye bayan hentbol liginde oynayan hentbolcuların fiziksel ve fizyolojik profilleri. Gazi Beden Eğitimi ve Spor Bilimleri Dergisi, 4(1), 1-8.

Bağırgan, T. (1990). Hentbolde Antrenman. Bağırgan Yayımevi, Ankara.

Bradshaw, R. J., Young, W. B., Russell, A., \& Burge, P. (2011). Comparison of offensive agility techniques in Australian rules football. Journal of Science and Medicine in Sport, 14(1), 65-69. https://doi.org/10.1016/j.jsams.2010.06.002

Brown, T. (2009). Speed and Agility: What Defines Them and How to Train for Both. NSCA's Performance Training Journal, 8(4), 12.

Chaouachi, A., Brughelli, M., Levin, G., Boudhina, N. B. B., Cronin, J., \& Chamari, K. (2009). Anthropometric, physiological and performance characteristics of elite team-handball players. Journal of Sports Sciences, 27(2), 151-157. https://doi.org/10.1080/0264041080 2448731

Mann, J. B., Ivey, P. A., Mayhew, J. L., Schumacher, R. M., \& Brechue, W. F. (2016). Relationship between agility tests and short sprints: Reliability and smallest worthwhile 
difference in National Collegiate Athletic Association Division-I football players. The Journal of Strength \& Conditioning Research, 30(4), 893-900. https://doi.org/10.1519/ JSC.0000000000001329

Michalsik, L. B., Madsen, K., \& Aagaard, P. (2015). Physiological capacity and physical testing in male elite team handball. J Sports Med Phys Fitness, 55(5), 415-429.

Póvoas, S. C., Ascensão, A. A., Magalhães, J., Seabra, A. F., Krustrup, P., Soares, J. M., \& Rebelo, A. N. (2014). Physiological demands of elite team handball with special reference to playing position. The Journal of Strength \& Conditioning Research, 28(2), 430-442. https://doi.org/10.1519/JSC.0b013e3182a953b1

Şentürk, İ. (2016). Elit hentbolcularda sürat, çeviklik ve kuvvet parametrelerinin pozisyonlara göre incelenmesi (Unpublished Master's dissertation, Marmara University, Turkey).

Shalfawi, S. A., Seiler, S., Tønnessen, E., \& Haugen, T. A. (2014). Shooting velocity aspects in Norwegian elite team handball. Serb J Sports Sci, 8, 33-40.

Taskin, C., Karakoc, O., Taskin, M., \& Dural, M. (2016). Analysis of reaction times and aerobic capacities of soccer players according to their playing positions. Journal of Education and Training Studies, 4(8), 23-26. https://doi.org/10.11114/jets.v4i8.1542

Taşkın, C., Taşkın, A. K., Üzüm, R. Y., \& Ak, A. E. (2020). Comparison of average and peak anaerobic power levels by locations in handball. European Journal of Physical Education and Sport Science, 8(6), 1-10.

Taşucu, E. (2002). Türk erkek hentbol milli takımının somatotip profilinin belirlenmesi (Unpublished Master's dissertation, Gazi University, Turkey).

Van den Tillaar, R., \& Ettema, G. (2004). Effect of body size and gender in overarm throwing performance. European Journal of Applied Physiology, 91(4), 413-418. https://doi.org/ 10.1007/s00421-003-1019-8

Yıldırım, K. (1997). Erkek hentbol milli takım oyuncularının bazı motorik ve antropometrik özelliklerinin değerlendirilmesi (Unpublished Master's dissertation, Gazi University, Turkey).

\section{Copyright Disclaimer}

Copyright for this article is retained by the author(s), with first publication rights granted to the journal.

This is an open-access article distributed under the terms and conditions of the Creative Commons Attribution license (http://creativecommons.org/licenses/by/3.0/). 